\title{
Jurnal Ekonomi dan
}

Manajemen Teknologi

(EMT)

\section{EDITORIAL POLICIES \\ JURNAL MANAJEMEN TEKNOLOGI}

\section{Aims and Scope}

The Journal of Technology Management Economics (EMT) is one of the scientific publications published by the KITA Institute. The purpose of this Journal is to support the theory and practice of development management in the dissemination of research findings in the field. This journal covers fields such as People's Knowledge and Management, Operations and Performance Management, Business Risk, Finance and Accounting, Entrepreneurship, Strategic Business and Strategic Marketing and Decision Making and Negotiation.

The Journal of Technology Management is registered by the Indonesian Institute of Sciences (LIPI) with Number SK: 0005.25496204 / JI.3.1 / SK.ISSN / 2017.02 - February 23, 2017 (starting edition Vol. 1, No. 1, January - June 2017) . Print ISSN: 2579-7972; ISSN Online: 2549-6204. Currently in the Indonesian Publication Index (IPI), Google Scholar, Indonesian Scientific Journal Database (ISJD), One Search Indonesia, Copernicus, Orchid, Academia, Researchgate, and in other international indexation processes.

\section{Section Policies}

\section{Article}

$\sqrt{ }$ Open Submissions

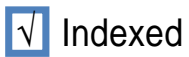

Peer Reviewed

Peer Review Process

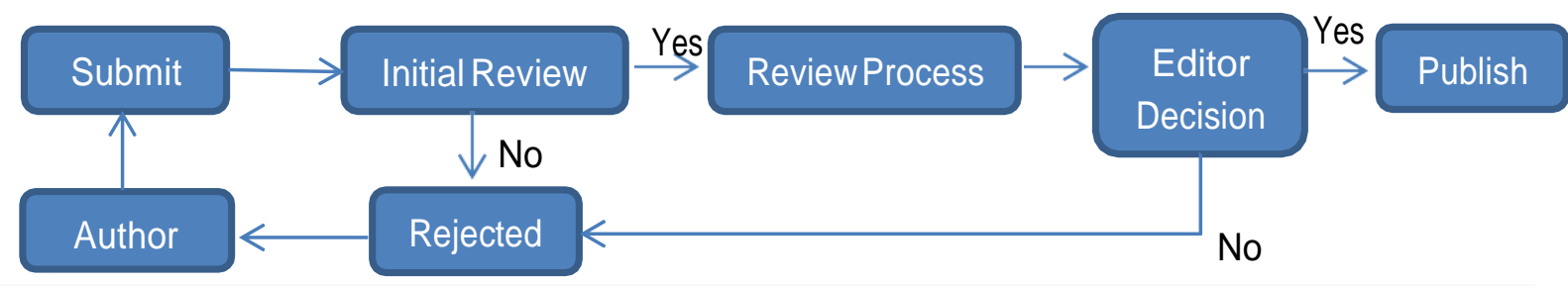

Once the manuscript has passed the initial review process, it will be further processed in a doubleblind review with an estimated time of between 1-3 months. After the double-blind review process, the author is promptly informed of the acceptance or revision or rejection of the manuscript. Along with the status of the paper, the author will receive the reviewer's comments. The reviewer's comments serve as guidance for improvements. Afterwards, the author is required to resubmit the revised manuscript based on the deadline given (only for manuscript revision).

Once the author receives the acceptance for publication, the manuscript will be edited for layout, figures, table, charts, and the author will be asked for approval along with a form as a Microsoft Word document, on which the author can request any changes required in the manuscript. After the final version of the manuscript is completed, it will be processed for publication. 
Open Access Policy

Jurnal Ekonomi Manajemen Teknologi (EMT) KITAprovidesimmediate open access of its content to make research results freely available to the public enabling greater global exchange of knowledge.

\section{Archiving}

The Journal utilizes the LOCKSS system to create a distributed archiving system among participating libraries that permits those libraries to create a permanent archive of the Journal for purposes of preservation and restoration.

\section{PublicationInformation}

The Journal is published two times annually in January and July. The Journal of Technology Management is registered by the Indonesian Institute of Sciences (LIPI) with Number SK: 0005.25496204 / JI.3.1 / SK.ISSN / 2017.02 - February 23, 2017 (starting edition Vol. 1, No. 1, January - June 2017) . Print ISSN: 2579-7972; ISSN Online: 2549-6204. Currently in the Indonesian Publication Index (IPI), Google Scholar, Indonesian Scientific Journal Database (ISJD), One Search Indonesia, Copernicus, Orchid, Academia, Researchgate, and in other international indexation processes.

\section{Profile in Google Scholar}

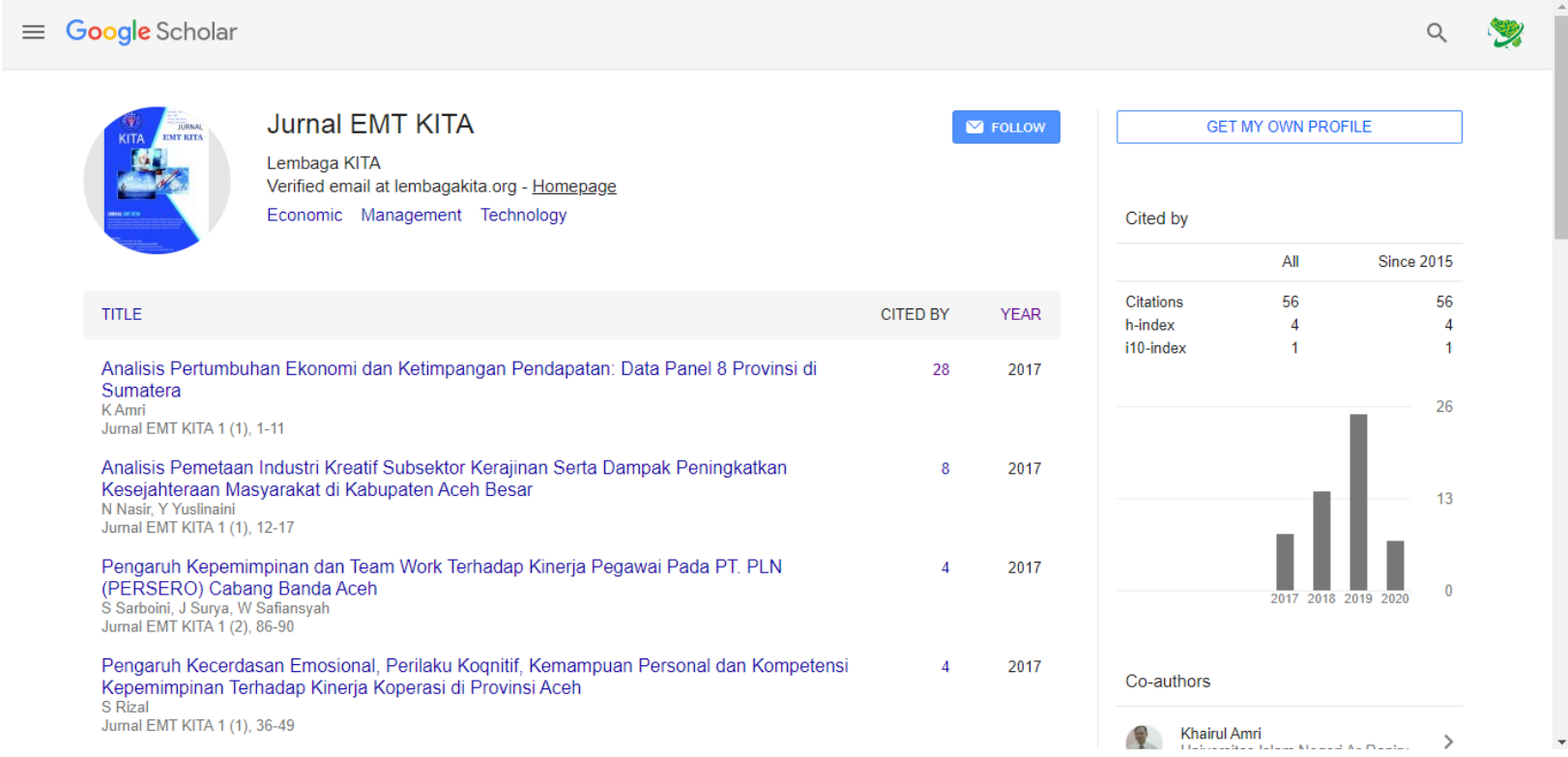


Profile in SINTA (S4)

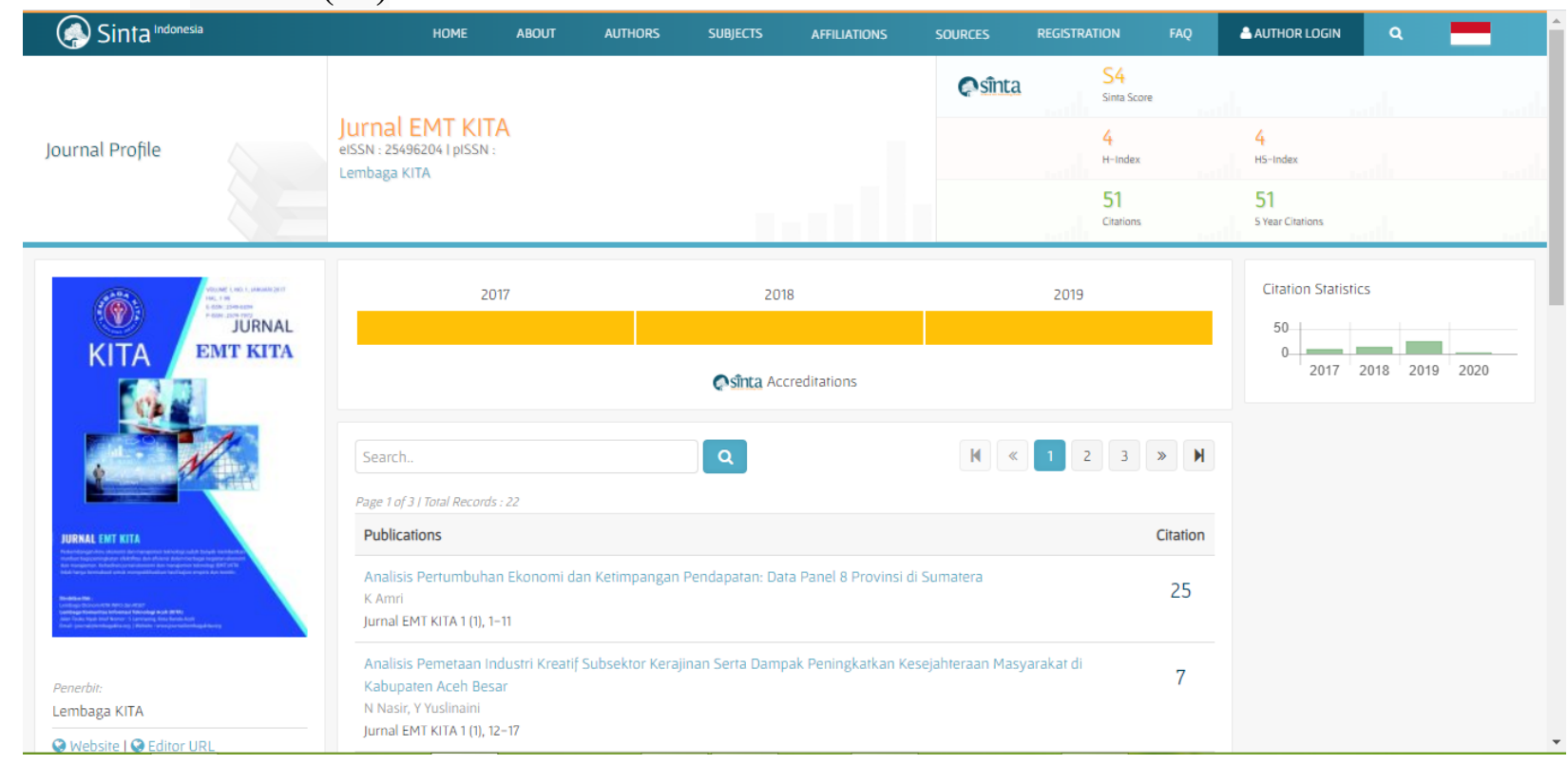

\section{Profile in Garuda}

C) GARUDA Home Publisher

\section{Journal / Conference}

Subject Suggest

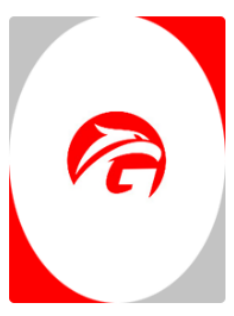

Article Per Year (5 Year)

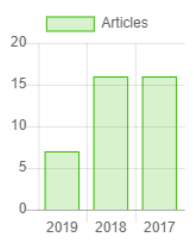

- Jurnal EMT KITA

emt $\bigcirc$ Website

Published by Lembaga Komunitas Informasi Teknologi Aceh

ISSN : 25797972 EISSN : 25496204 DOI :

Core Subject : Economy,

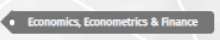
to support the theory and practice of development managerrestin the dissemination of research findings in the field. This journal covers fields such as Peoplés Knowiedge and Maragetement, Operations and Performance Management, Business Risk, Finance and Accounting, Entrepreneurstip. Strategic Business and Strtegic Marketing and Decision Making and Negotiation

Arjuna Subject:

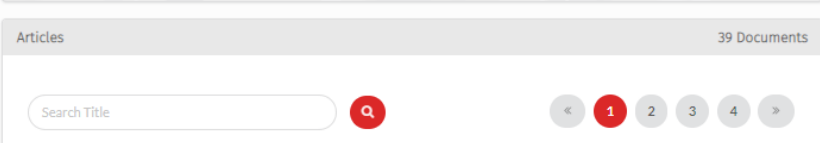

THE ROLE OF ACCOUNTING INFORMATION IN THE DETERMINATION TO MUZAKKI'S DECISIONS FOR ZAKAT PAYMENT

Iskandar, Ey; Iskandar, Deddy; Maulana, Hafizh

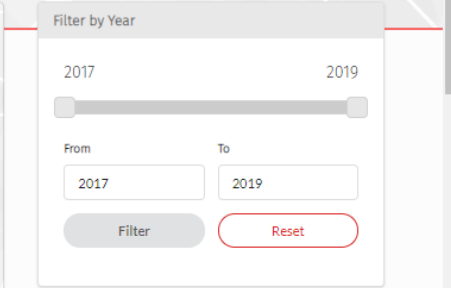

Fitter By Issues

All Issue

Vol 3, No 2 (2019): Journal EMT KTTA

Vol 3, No 1 (2019): Journal EMT KITA

Vol 3, No 1 (2019): Journal EMT KIT

Vol 2, No 2 (2018): Journal EMT KITA

Vol 2, No 1 (2018): Journal ENT KITA

Vol 1, No 2 (2017): lournal EMT KITA 
Profile in Indonesian Publication Index (IPI)

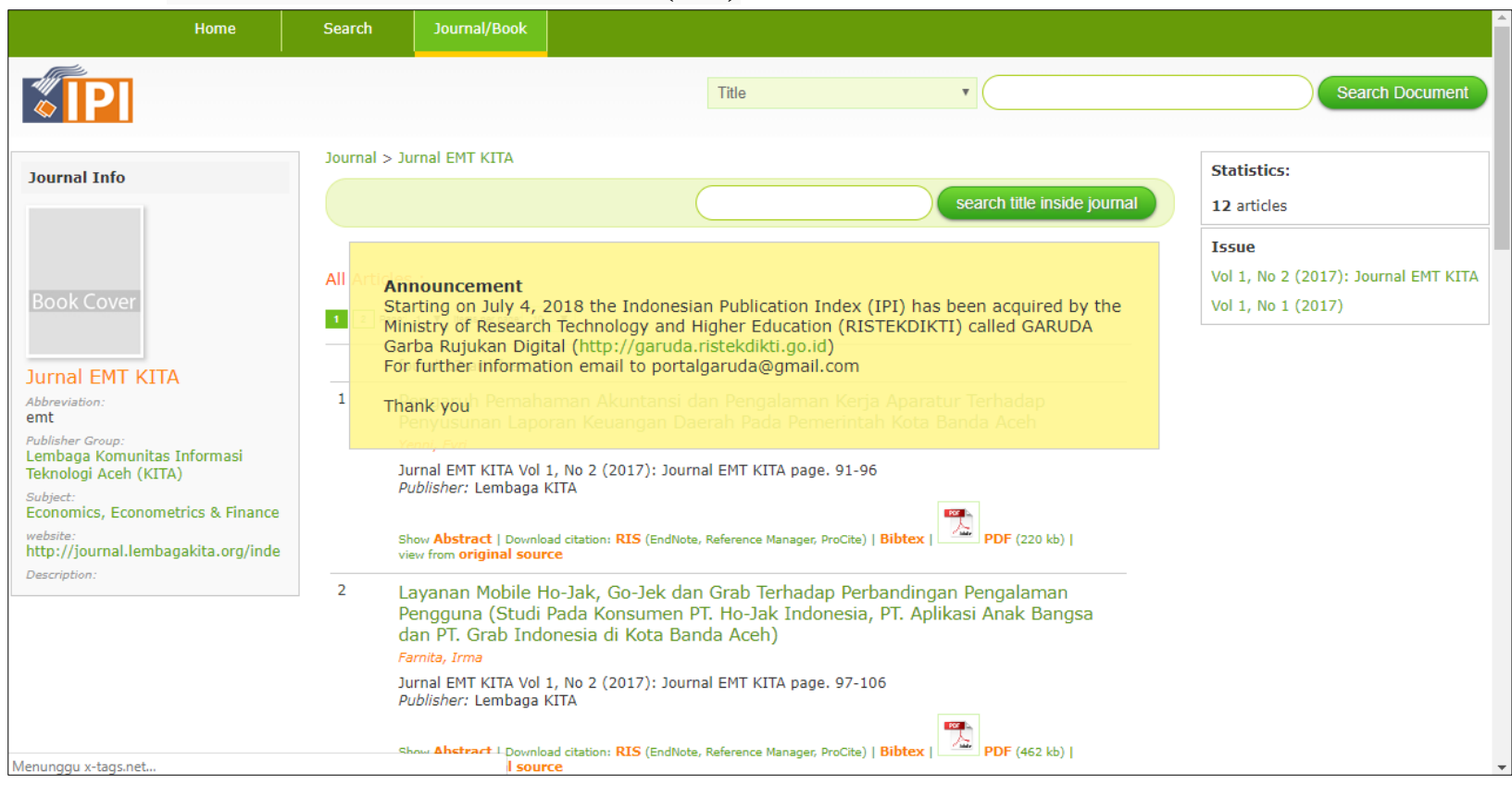

\section{Profile in OneSearch}

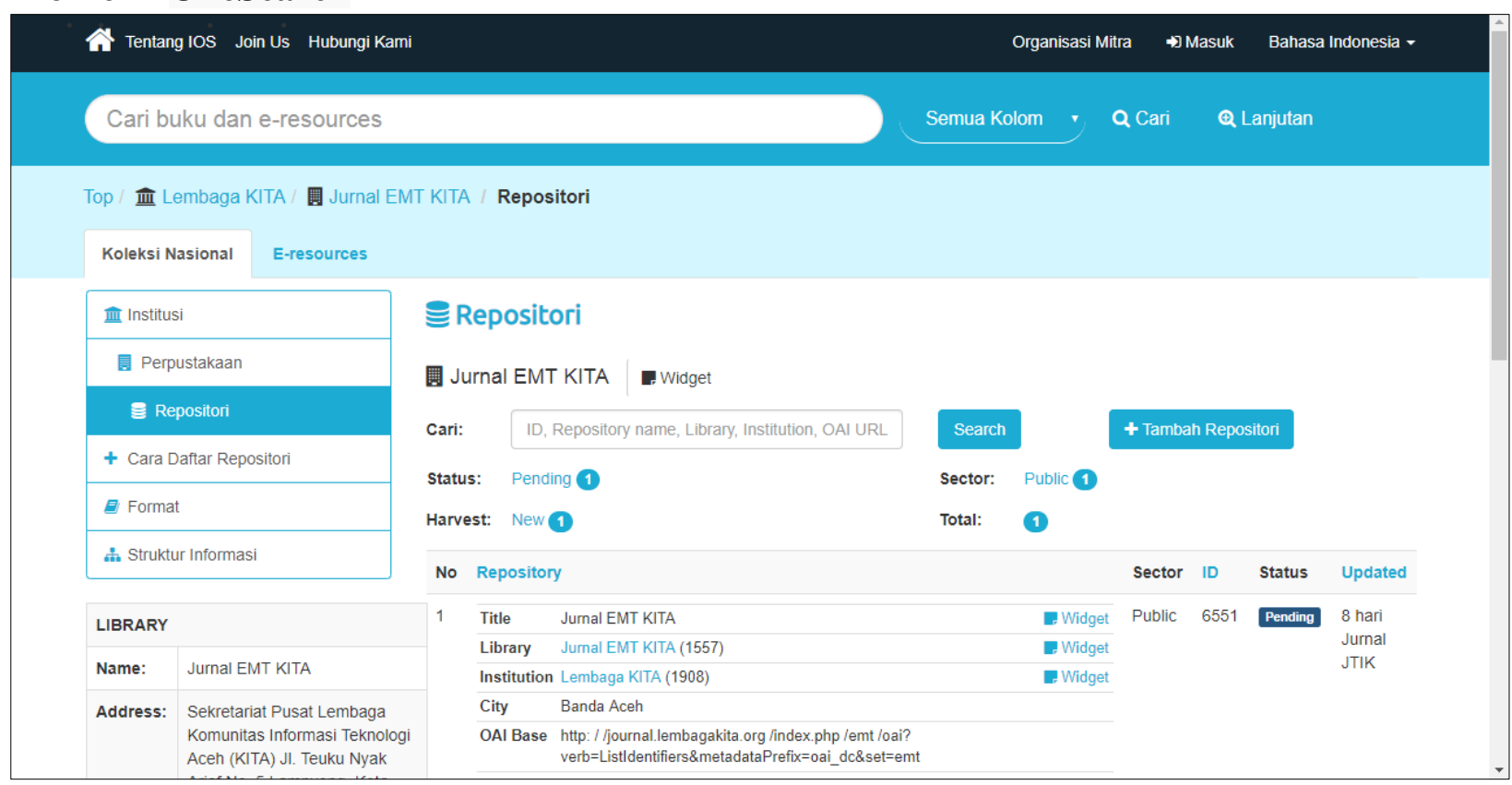


Profile in Orcid

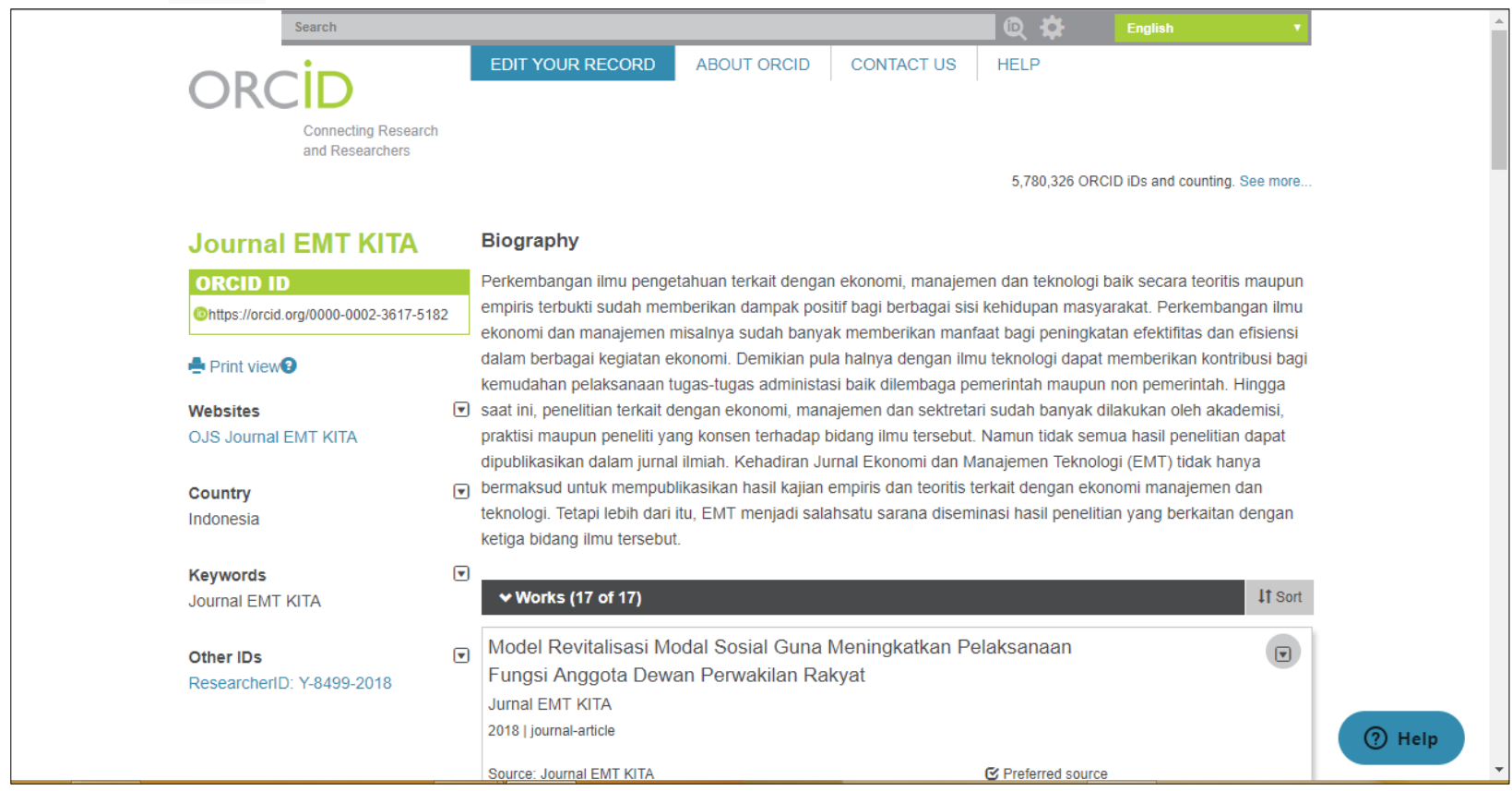

\section{Profile in Index Copernicus}

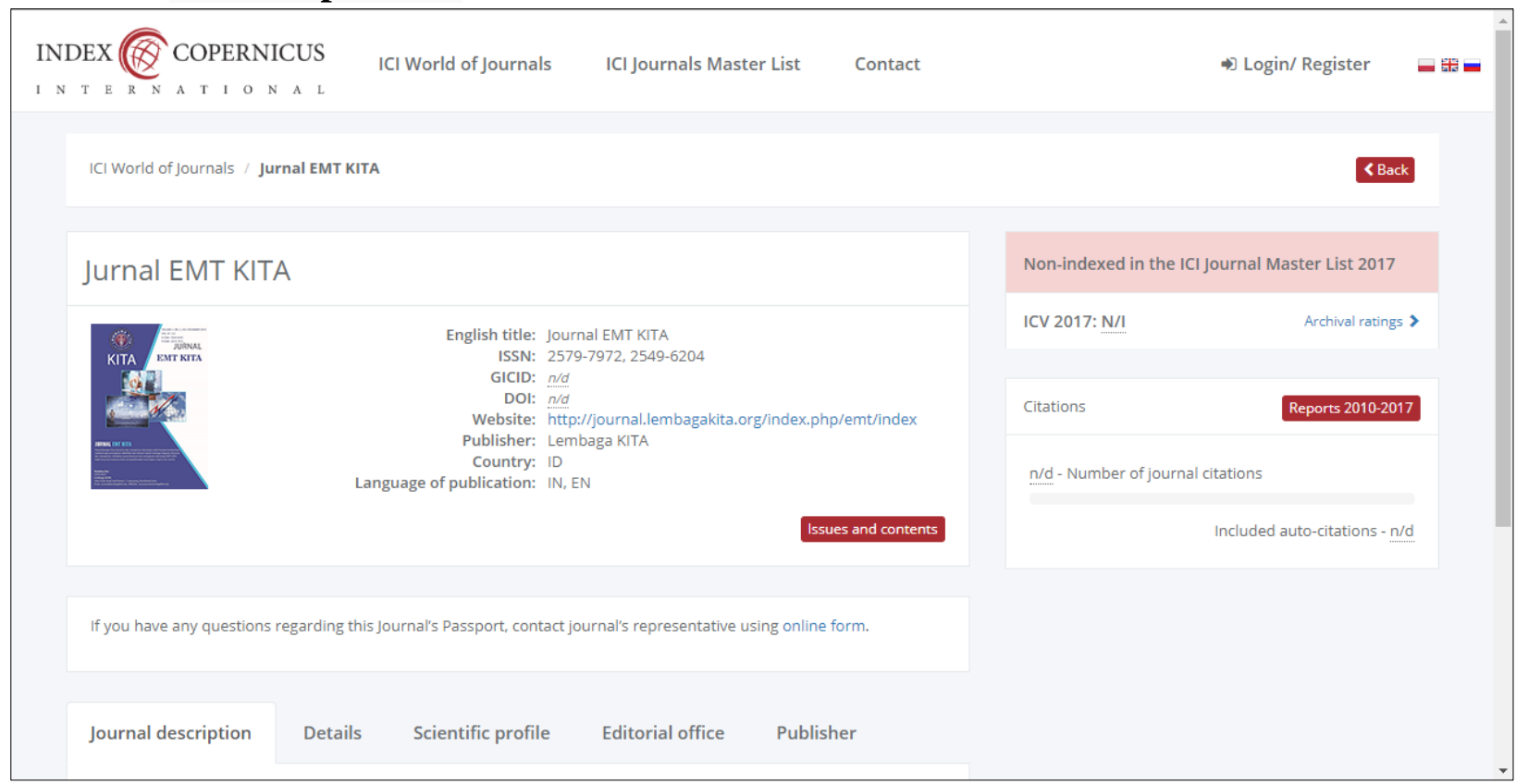


Profile in International Scientific Indexing (ISI)

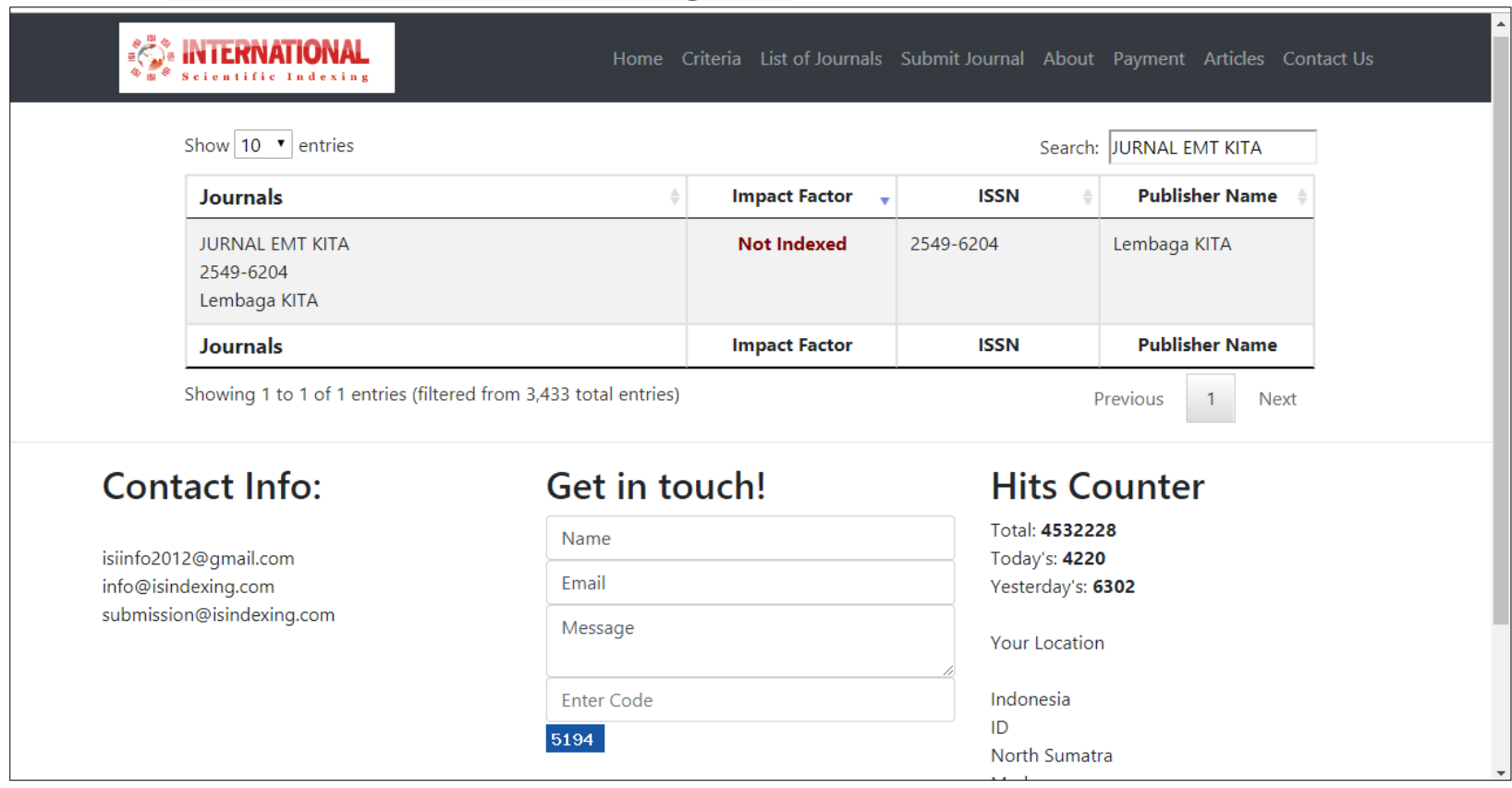

\section{Profile in ResearcherID}

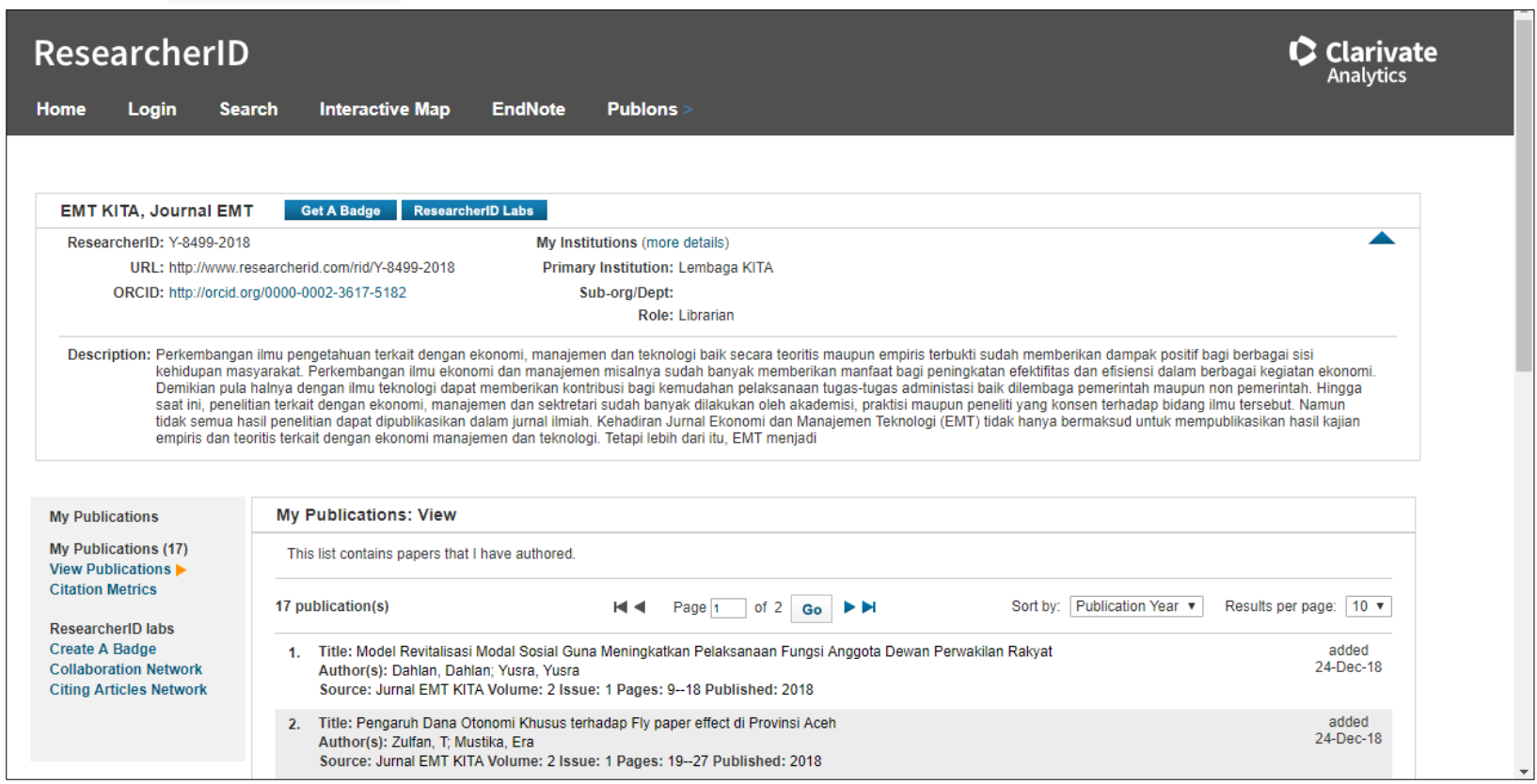


Profile in Academia

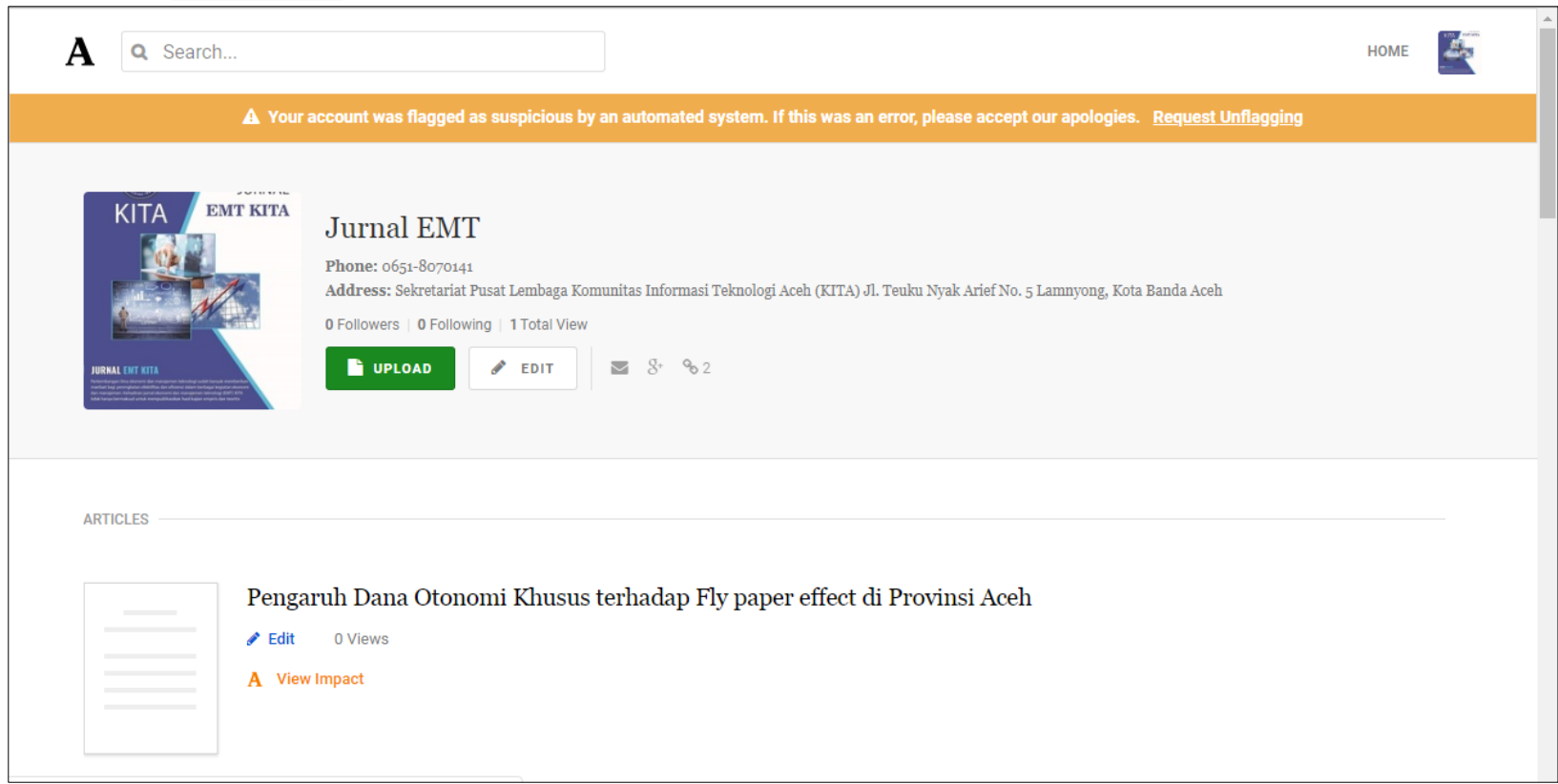

\section{Profile in Publons}

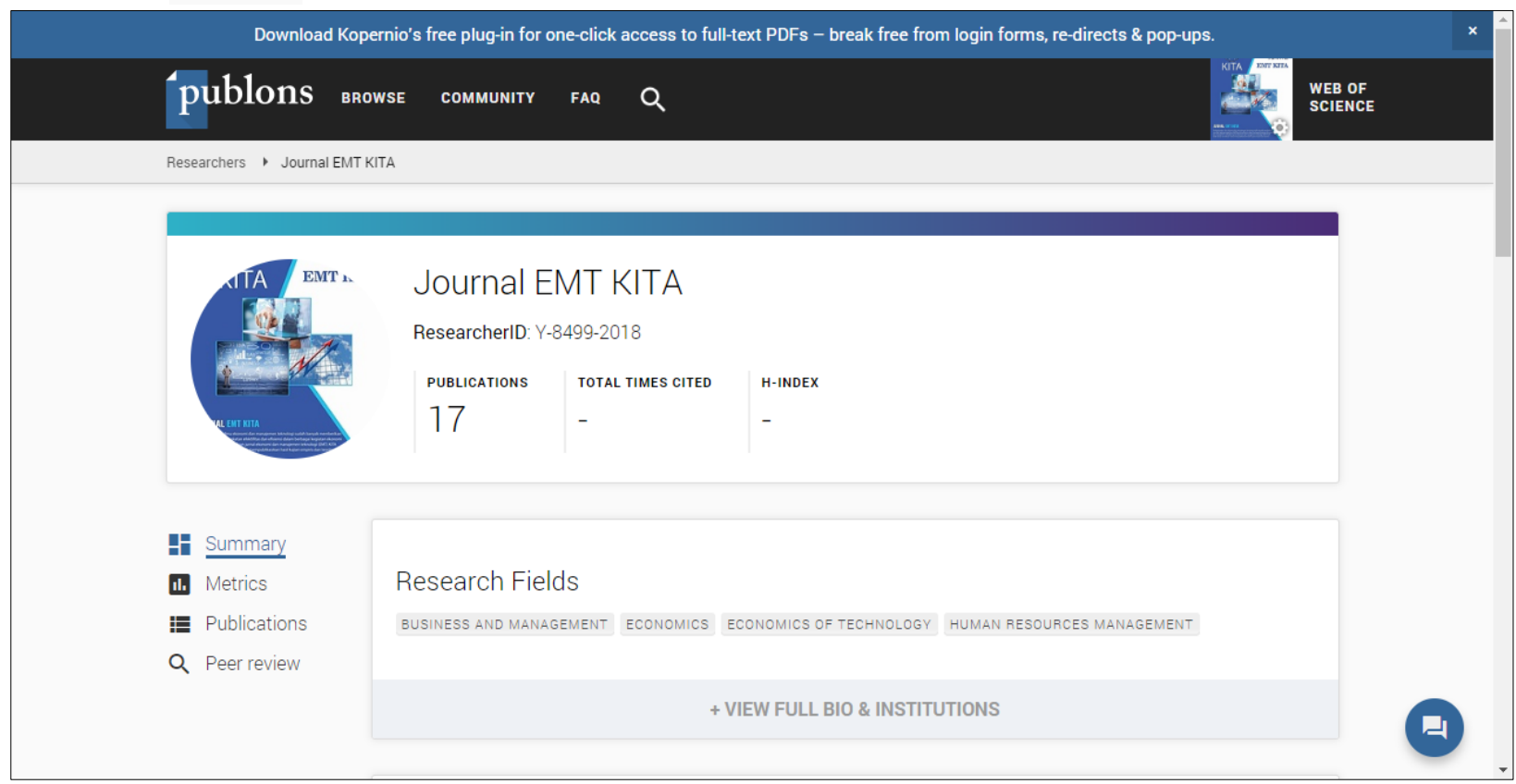


Profile in Scribd

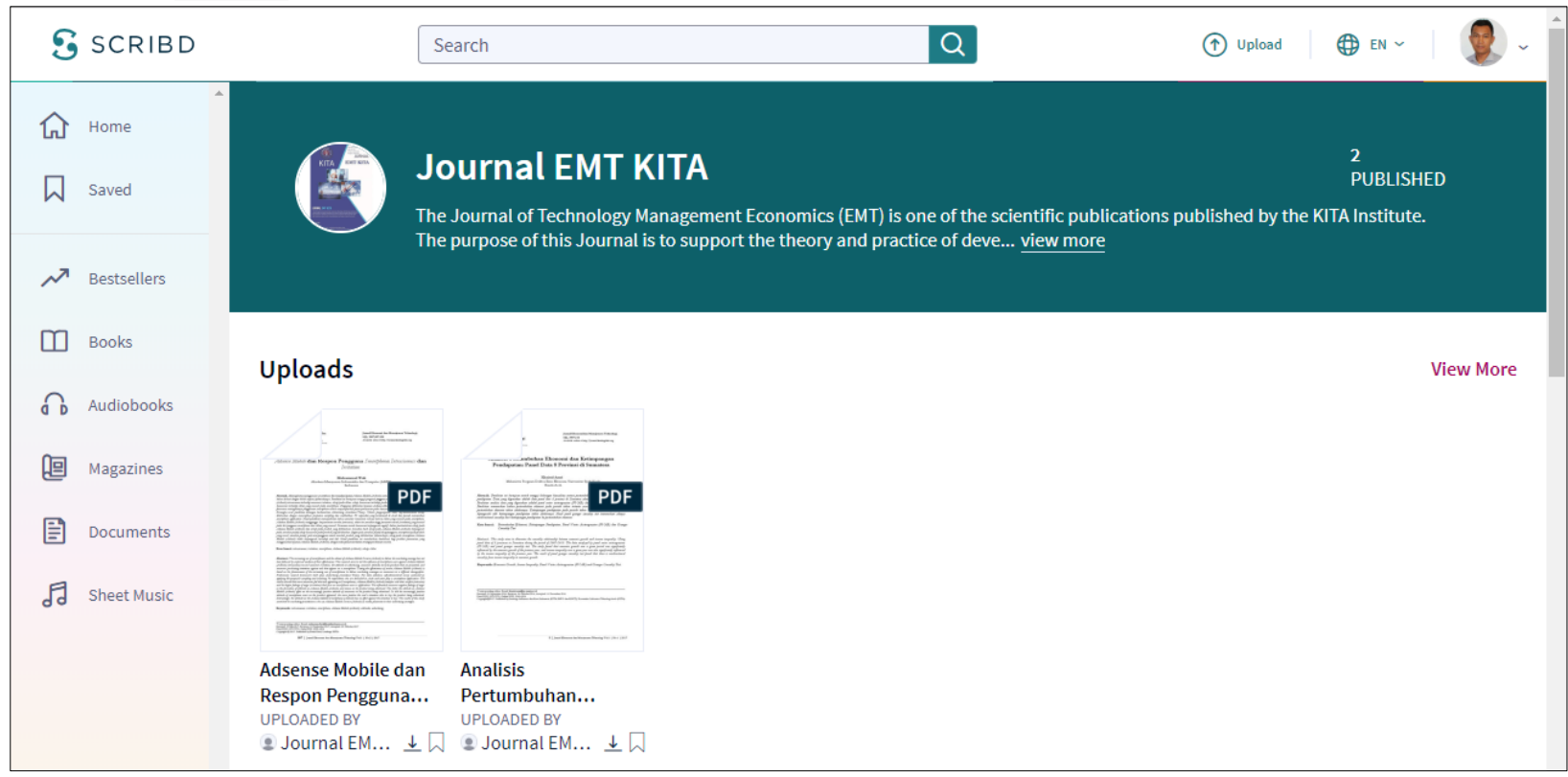

\section{Profile in End Note}

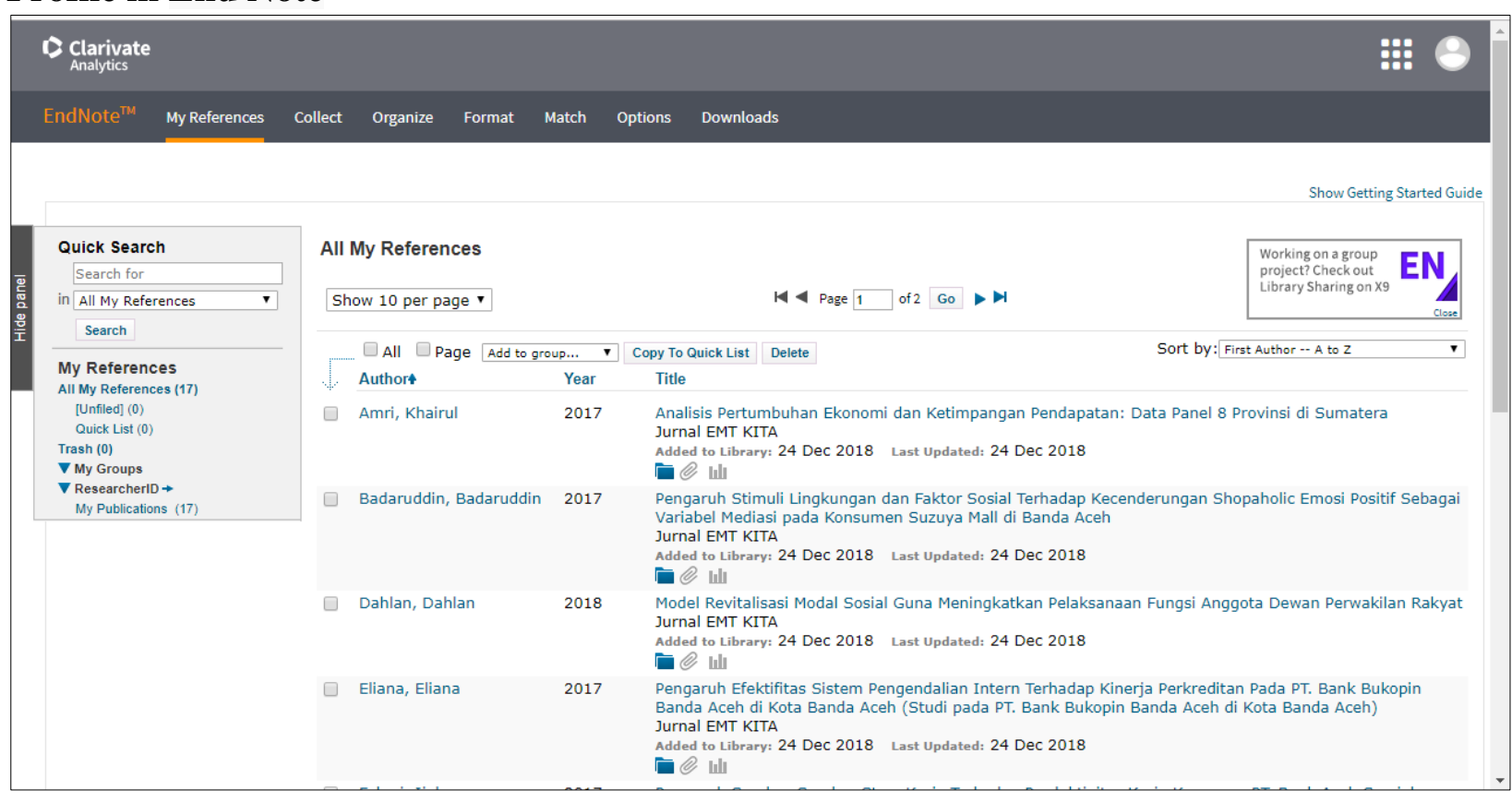

